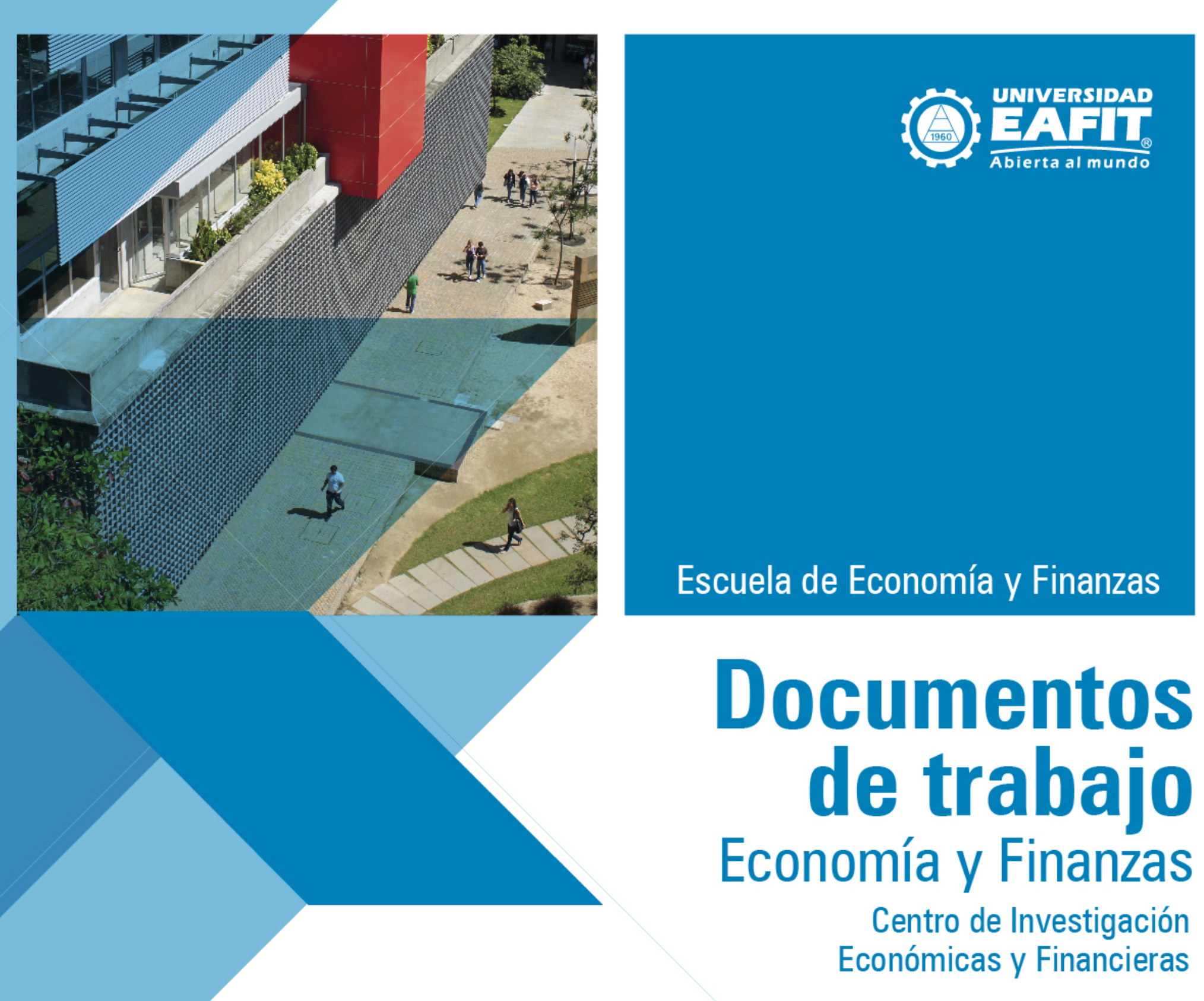

No. 12-32 Homer: A Forerunner of Neoclassical 2012 Economics

Posada, Carlos E.

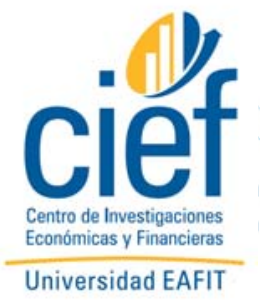




\title{
Homer: A Forerunner of Neoclassical Economics
}

Carlos Esteban POSADA ${ }^{\text {a); }) ~}$

a) Universidad EAFIT, Medellín, Colombia

\begin{abstract}
Homer clearly expressed the economic problem of choosing the best option among several alternatives given a certain set of restrictions. In the Odyssey he specifically wrote about the minimum cost choice. This kind of problem, as is well known, is at the heart of the neoclassical economics. We can therefore consider Homer a forerunner of this school of thought. This hypothesis contrasts with those of Trever [9], Schumpeter [8] and Schefold [7].
\end{abstract}

Journal of Economic Literature classification: B13; B31

Keywords: Odyssey, minimum cost choice, neoclassical economics

b) The author declares that there is no conflict of interests regarding the publication of this paper. 


\section{Introduction}

Homer was the first Greek poet (and first intellectual) to clearly express the economic problem of choosing the best option between several alternatives given a certain set of restrictions. Specifically in the Odyssey, Homer (Homer [4]) discussed the problem of minimum cost choice and understood that human beings must often weigh different options given certain constraints. Because the problem of minimum cost choice is at the heart of neoclassical economics ${ }^{\mathrm{i}}$, we can consider Homer a forerunner of this school of thought ${ }^{\mathrm{ii}}$ and the rational choice theory ${ }^{\mathrm{iii}}$.

In what follows, I briefly summarize the verses in the Odyssey (1996) upon which I make this claim. I then critique the argument advanced by Trever [9], and subsequently defended by Schumpeter [8] and Schefold [7], that Homer has nothing to add to our understanding of economic reasoning or to our knowledge of the history of economic analysis. To date, I am unaware that any other author has revealed how Homer grapples with analytic problems taken up by neoclassical economics.

\section{The Proof}

Evidence in favor of my argument is found in the dialogue between Odysseus and Circe in Book Twelve of the Odyssey. In this part of the epic, Circe tells Odysseus that he must choose between three different routes of navigation upon leaving her island (and past the island of the Sirens), none of which is without cost ${ }^{\mathrm{iv}}$. The first route, which is the most dangerous, entails sailing through the Clashing Rocks. No one, except for Jason and his crew (thanks to Goddess Hera's love for Jason), has survived going this way. The other two options involve passing through a strait inhabited by the two eternal monsters, Scylla and Charybdis. By sailing through the end of the strait where Scylla lives, Odysseus risks being attacked and losing six members of his crew. Yet by sailing through the other end, Charybdis could destroy his boat and kill his entire crew. 
According to Circe, Odysseus's best option is to attempt to sail by Scyllav . In our terms, this is the minimum cost option ${ }^{\mathrm{vi}}$. In fact, this is the choice that Odysseus makes. We see therefore that Homer was preoccupied with the problem of choosing the best option among several alternatives given a certain set of restrictions.

\section{The Conventional Wisdom}

My argument contradicts that made by Albert Trever [9]. Trever argued that any material of interest in Homer applies not to any specific mode of economic reasoning (e.g. minimum cost), but rather to a history of economic conditions (Trever [9], Note 2, P. 14). This is not unlike the position taken by Joseph A. Schumpeter ([8], pp. 52-54): i.e. that there is nothing of interest regarding modes of economic analysis before Plato. More specifically, Schumpeter asserts that the works of the Greek poets and historians prior to Plato are relevant only when examined from the point of view of the history of facts and economic opinions ${ }^{\text {vii }}$.

More recently, Schefold ([7], pp. 111-128) has examined the works of Homer to find the roots of Greek economic thought. According to Schefold, in Homer the reader may find passages interesting only from the point of view of the history of economic facts or opinions, or from the point of view of moral precepts on issues that we now regard as economic ones. In my view, therefore, Schefold does not dispute the position taken by Trever and Schumpeter ${ }^{\text {viii }}$.

Without denying the important contributions these authors have made for our understanding of ancient Greek economic thought, I do believe that Homer expressed in a clear way a problem that belongs to the core of neoclassical economics.

\section{REFERENCES}

[1] Backhouse, Roger E. 2002. The Ordinary Business of Life: A History of Economics 
from the Ancient World to the Twenty-First Century. Princeton and Oxford: Princeton University Press.

[2] Blaug, Mark. 1968. Economic Theory in Retrospect (Revised Edition). Homewood: Richard D. Irwin, Inc.

[3] Ekelund Jr., Robert B., and Hébert, Robert F. 1997. A History of Economic Theory and Method (Fourth Edition). New York: McGraw-Hill.

[4] Homer. The Odyssey. Translated by Robert Fagles. New York: Penguin Classics Deluxe Edition. 1996.

[5] Knox, Bernard. "Introduction". The Odyssey. Translated by Robert Fagles. New York: Penguin Classics Deluxe Edition. 1996, pp. 3-64.

[6] Lovett, Frank. 2006. "Rational Choice Theory and Explanation.", Rationality and Society 18(2): $237-272$.

[7] Schefold, Bertram. 1997. "Reflections of Ancient Economic Thought in Greek Poetry". In B. B. Price, ed., Ancient Economic Thought. Volume 1, London: Routledge, pp. 99-145.

[8] Schumpeter, Joseph A. 1954. History of Economic Analysis, New York: Oxford University Press (Reprint as an Oxford University Press paperback in 1986). 
[9] Trever, Albert A. 1916. A History of Greek Economic Thought. Chicago: The University of Chicago Press. Note 2, p. 14. 


\section{Endnotes}

${ }^{\mathrm{i}}$ I use the definition of Blaug [2] of neoclassical economics, namely, post-classical economics excluding the Marxist and Keynesian theories. On the choose of the least cost option (taking into account a set of constraints) as an issue belonging to the heart of neoclassical economics, see Blaug [2]: “After 1870...For the first time, economics truly became the science that studies the relationship between given ends and given scarce means that have alternative uses." (Blaug [2], pp. 299-300).

ii In this paper I'm using the hypothesis more accepted today: Homer did exist and wrote the Odyssey in some date between 725 and 675 в. C. ("The most likely date for the composition of the Iliad is the fifty years running from 725 to 675 B. C.; for the Odissey, somewhat later in the period": Knox [5], p. 19).

iii On this theory, its general meaning, scope and limitations, see Lovett [6].

${ }^{\text {iv }}$ Homer [4]. The Odyssey, pp. 273 - 275 (see list of references).

${ }^{\vee}$ Circe tells Odysseus: “... hug Scylla's crag-sail on past her- top speed! Better by far to lose six men and keep your ship than lose your entire crew" (op. cit., p. 274).

${ }^{\text {vi }}$ According to the neoclassical economics this problem is an economic one, and the consequences related to the three alternatives are real costs.

${ }^{\text {vii }}$ Schumpeter ([9], Note 1, p. 54).

viii Ekelund and Hébert ([3], pp. 11-12), and Backhouse ([1], pp. 11-12) share the Schefold [7]'s hypothesis. 